This is an author produced version of a paper published in Biodiversity and Conservation.

This paper has been peer-reviewed but may not include the final publisher proof-corrections or pagination.

Citation for the published paper:

Thomas Ranius, Victor Johansson, Lenore Fahrig. (2011) Predicting spatial occurrence of beetles and pseudoscorpions in hollow oaks in southeastern Sweden. Biodiversity and Conservation. Volume: 20, Number: 9, pp $2027-$ 2040.

http://dx.doi.org/10.1007/s10531-011-0072-6.

Access to the published version may require journal subscription.

Published with permission from: Springer.

Standard set statement from the publisher:

"The final publication is available at Springer via http://dx.doi.org/ 10.1007/s10531-0110072-6"

Epsilon Open Archive http://epsilon.slu.se 
Should be cited as: Ranius, T., Johansson, V. \& Fahrig, L. (2011) Predicting spatial occurrence of beetles and pseudoscorpions in hollow oaks in southeastern Sweden. Biodiversity and Conservation 20: 2027-2040.

http://download.springer.com/static/pdf/462/art\%253A10.1007\%252Fs10531-011-00726.pdf?auth66=1392714601_fbd2eb9008b1df71ab71228710af65a8\&ext=.pdf

\section{Predicting spatial occurrence of beetles and pseudoscorpions in hollow oaks in southeastern Sweden}

Thomas Ranius $^{\mathrm{a}, *}$, Victor Johansson ${ }^{\mathrm{b}}$, Lenore Fahrig ${ }^{\mathrm{c}}$

${ }^{a}$ Department of Ecology, Swedish University of Agricultural Sciences, Uppsala, Sweden

${ }^{\mathrm{b}}$ Department of Ecology, Swedish University of Agricultural Sciences, Uppsala, Sweden, Email: victor.johansson@ @lu.se

${ }^{c}$ Ottawa-Carleton Institute of Biology, Carleton University, Ottawa, Ontario, Canada Email: lenore_fahrig@ carleton.ca

Running head: Spatial occurrence of beetles and pseudoscorpions in hollow oaks

* Corresponding author. Dep. of Ecology, SLU, Box 7044, SE-750 07 Uppsala, Sweden, Email: thomas.ranius@slu.se, Phone: ++46-18-67 2334. 


\section{Abstract.}

We modelled presence/absence per tree of beetles and pseudoscorpions living in tree hollows in relation to trunk circumference, habitat openness, and connectivity (= density of hollow oaks in the surrounding area), using data from 281 oaks. The presence/absence models were then used to predict species' occurrences in a county $\left(11,600 \mathrm{~km}^{2}\right)$ in southeastern Sweden. For eight of the nine species, the most parsimonious occupancy model included a positive relationship with connectivity and at least one tree characteristic. Occupancy underestimates from occurrence records - the ratio of the area of occupancy based on our predictive model to the area of occupancy based on occurrence records - varied between 3 and 83 among species when using occurrence records up to 1993, with significantly larger underestimates for smaller beetle species. Today (after extensive surveys), underestimation has decreased to $1.3-25$, confirming that calculations solely based on species occurrence records greatly underestimate the area of occupancy. We suggest this should be taken into account to a greater extent and in a clearer way than today when constructing redlists. The radius of the connectivity measure that generated the best fit varied between $135 \mathrm{~m}$ and 2,857 $\mathrm{m}$ among species, with longer distances for more threatened species. Consequently, preservation of the most threatened species (Elater ferrugineus and Tenebrio opacus) requires conservation efforts at larger spatial scales than required to protect Osmoderma eremita, which frequently has been used as an indicator and umbrella species.

Keywords: connectivity, Quercus robur, redlist, spatial occurrence patterns, scale, spatial extent

\section{Introduction}

Red-listing aims at assessing species' extinction risks. Except for a very limited number of well-known species, red-listing is typically based on observational data, and only rarely on monitoring data of population trends or quantitative analyses of extinction risks (e.g. Hallingbäck et al. 1998; Komonen et al. 2008; Newton and Oldfield 2008). A difficult but important task is how to handle the fact that an unknown number of subpopulations are 
unrecorded. In Sweden, for instance, "area of occupancy", a measure used in red-listing, is obtained by multiplying the area of grid squares with recorded occurrences with an estimated factor of underestimation. This factor is defined as the inverse of the proportion of all subpopulations assumed to have been recorded. However, this is not supported by empirical evidence; we are not aware of any study in Sweden or elsewhere that has estimated the proportion of all occurrences that have been recorded under different circumstances.

Our first aim of this study was to estimate the degree of underestimation of the area of occupancy of seven beetle and two pseudoscorpion species in Sweden. We did this by investigating how per-tree occurrence of each species is related to habitat openness, trunk circumference, and connectivity (= density of hollow oaks in the surrounding area). We then estimated factors of underestimation by comparing predicted occupancy to the localities that are known in 2009 to be occupied (after extensive surveys; Jansson 2006) and were known in 1993 years ago to have been occupied (mainly based on incidental records from amateur entomologists), in an 11,600 $\mathrm{km}^{2}$-large Swedish county, where hollow trees have been surveyed. We predicted a negative relationship between species body size and underestimation on the assumption that smaller species are harder to detect.

Metapopulation theory (Johst et al. 2002) and studies of butterflies (Kotiaho et al. 2005; Maes and van Dyck 2001) suggest that less mobile species are more susceptible to habitat loss than are more mobile species. However, some theoretical and empirical studies have shown the opposite; more mobile species can be more susceptible to habitat loss due to a higher risk of dispersal mortality (reviewed in Fahrig 2007).

Our second aim was to test whether the spatial scale of effect is related to redlist category across the nine species in our study. The scale of strongest effect is thought to be positively related with the movement range of the species (e.g. Schmidt et al. 2008). For this we first conducted multi-scale analyses of the effect of landscape structure (connectivity) on occurrence of each species. We then tested for a cross-species relationship between the spatial scale of effect of the landscape and red list category to determine whether species with smaller or larger scales of effect (i.e. dispersal ranges) are in higher redlist categories. 


\section{Methods}

\section{Collecting field data on invertebrates}

Five areas were surveyed, all in the county of Östergötland, southeast Sweden (Table 1; Fig. 1). Areas with large differences in the density of hollow oaks were selected, to obtain a wide variability in connectivity among the studied trees (cf. Eigenbrod et al. 2011). Before the invertebrate surveys, we identified potentially suitable trees by visiting sites with large or hollow trees, which we found using information from previous inventories (see Ranius et al. 2010, for details). In Omberg, Kättilstad and Bjärka Säby, pedunculate oak (Quercus robur L.) was by far the dominant tree species among hollow trees. In Skärkind and Sankt Anna there were also other tree species - birch (Betula verrucosa Ehrh.), aspen (Populus tremula L.), linden (Tilia chordata Mill.), and apple (Malus sylvestris (L.)). However, our observations of these hollows indicated that the amount of wood mould (i.e. loose material of dead wood in the tree hollows) they contain is generally low. Ranius et al. (2010) found a strong positive relationship between wood mould and species occurrence. Given the low volume of wood mould in non-oak species we chose to restrict our sampling to larger oak hollows. There are hollow-dwelling species for which other tree species are also important, but we avoided that problem by only analysing beetle and pseudoscorpion species that have been observed predominantly in hollows in oaks $(>90 \%$ of the findings made in the hemiboreal region in Sweden, according to a database provided by the Swedish Species Information Centre). We acknowledge that, to some extent, the very strong predominance for oaks in the observations may reflect that oaks have been surveyed more frequently than other species, although invertebrates have been surveyed in hollow trees of other species as well (e.g. Jansson 2006).

When estimating connectivity, we used data on the position of every hollow oak within the study landscapes and 4-km wide buffer zones around these landscapes. We combined a tree survey by the County Administration Board (Claesson and Ek 2009) with information from our own field survey to obtain data on the positions of all oaks with hollows containing at least 21 of wood mould. The volume of wood mould was estimated by examining the hollows. When hollows were impossible to reach, trees with entrance holes with diameters > $10 \mathrm{~cm}$ were included. At least some of our study species have been observed also in trees with smaller entrance holes (e.g. Osmoderma eremita; Martin 1993), but it is not known how frequently this occurs. Trees with smaller entrance holes usually have amounts of wood mould 
that probably are too small for the study species, because there is a strong positive correlation between wood mould volume and size of the entrance hole (Ranius et al. 2009a). Connectivity was calculated by summing the hollow oaks with wood mould within a circle of a given radius; we calculated connectivity using radii within a range from 25 to $4,000 \mathrm{~m}$. We identified the scale that generated the minimum residual deviance for the total model graphically, with an accuracy of $1 \mathrm{~m}$. This has been found to be a surprisingly good connectivity measure for this study system, in comparison to more complicated connectivity measures (Ranius et al. 2010). Note we could not use connectivity measures that include species occurrence because we were using the prediction model in a landscape where we did not have species occurrence data available for most trees.

Sampling was done by taking eight litres of wood mould from a hollow in each tree (or the total volume, if less than eight litres was available). The wood mould was sieved, and spread out on a white sheet in the field. We examined the material for an hour, and then returned it to the hollow. Presence/absence of larvae (only possible to determine to species for Osmoderma eremita and Elater ferrugineus), adults (beetles and pseudoscorpions) or adult beetle body parts (elytra, pronota, or heads of beetles) was recorded. There is a strong correlation between the occurrence of adult beetle body parts and live adult beetles (Ranius and Nilsson 1997). As most of the species records are based on body parts that may remain in the trees over several years, at least for these species the result is not sensitive to the fluctuations of population sizes or weather between years. For the two pseudoscorpion species this sampling method seems to be efficient (Ranius and Wilander 2000), and a comparison of different sampling methods showed that this was the most efficient for the seven beetle species analysed (one species for which this method was not efficient was excluded from analyses; Ranius and Jansson 2002). Hollows up to $5 \mathrm{~m}$ from the ground were sampled. In Omberg and Skärkind, hollows at the ground level were avoided. In Kättilstad and Bjärka Säby, we sampled as many hollow oaks as possible $(61 \%$ and $46 \%$ of all hollow oaks, respectively). In Omberg, Sankt Anna, and Skärkind, all trees in smaller stands were selected, while in bigger stands, trees were randomly selected (resulting in sampling of $14 \%, 29 \%$ and $16 \%$ of all hollow oaks, respectively). For each tree, we measured two characteristics that have been found to influence the occurrence of the inhabiting species (Ranius and Wilander 2000; Ranius 2002a): habitat openness and trunk circumference. Habitat openness was the 
vertical projection of the foliage at a $2 \mathrm{~m}$ wide zone around the tree crown: $>75 \%(0), 25 \%-$ $75 \%$ (1) or $<25 \%$ (2). The trunk circumference was measured $1.3 \mathrm{~m}$ above ground. In a previous analysis, we found that height above ground of the entrance, direction of the entrance, and wood mould volume also affected species occurrence (Ranius et al. 2010), but we did not include these variables in the present study, as the aim was to predict species occurrence in a whole county, and we did not have data on these variables for every tree in the county. We found no significant correlation ( $p<0.05$, Pearson correlation coefficient) between any of these three variables and connectivity at scales between 25 and 4,000 m, which implies that there is little risk that observed correlations between connectivity and species occurrence are due to confounding effects of these variables.

\section{Fitting models predicting species occupancy}

We built two sets of models; the first was aimed at conservative tests of the local and landscape variables affecting occurrence of each species, and the second was to be used in making predictions of occurrence in landscapes not included in our study. For the first set we constructed generalized linear mixed-effect models with a binomial error distribution and a logit link function for each species (Quinn and Keough 2002). Species presence/absence per tree was the dependent variable, habitat openness, trunk circumference, and connectivity were the independent fixed factors and landscape identity was a random factor. By including landscape identity in the model, we took into account that the occupancy per study landscape may be affected by some unmeasured landscape-scale characteristic(s). We used these models as conservative tests of the effects of the tree variables and connectivity on species occupancy The tests are conservative because some of the variance actually explained by the fixed effects may in fact be attributed to the random effect for landscape identity, if the fixed effects differ among landscapes. For example, since the density of hollow oaks differs among study landscapes, connectivity is confounded to some extent with landscape identity, so part of any real effect of connectivity will be interpreted as a landscape identity effect rather than as a connectivity effect.

To make predictions to landscapes other than those where the data were collected, we therefore also fit models that did not include a random effect for landscape identity. Not only would it be impossible to include the effect of landscape identity when predicting occupancy 
in other landscapes but also, in making predictions to other landscapes, we wish to assume that the apparent effect of the tree variables and connectivity are actually attributable to those variables rather than to some other unmeasured variable(s) that differs among the sampled landscapes. We modelled species occupancy in relation to habitat openness, trunk circumference and connectivity using a generalized linear model with a binomial error distribution and a logit link function.

For the first set of models, landscape identity was included in the models irrespective of how it affected AIC, while the variables at the tree level were included only if they decreased the AIC value. The latter was also true for the second set of models in which landscape identity was not included. The AIC value was calculated as $-2 \log$-likelihood $+2 k$, where $k$ is the number of parameters in the logistic regression model plus one for the radius of the connectivity measure, as that was also estimated when fitting the model. For both sets of models, we calculated the explained deviance $(\%$, the proportion of variability in a data set that is accounted for by the statistical model, which means it is an analogue to $R^{2}$ ) and for the first set of models also $p$ values (from log likelihoods) since here we were interested in testing hypotheses.

\section{Predicting species occupancy in a whole county}

We used the predictive models (above) to predict species occupancy in the county of Östergötland, which is about $11,600 \mathrm{~km}^{2}$. To predict occupancy of our study species, we used tree survey data from the County Administration Board (Claesson and Ek 1999). Using aerial photos, they have identified all sites where large trees might be present. These sites were surveyed on ground, and trees that are large or hollow were individually mapped. The County Administration Board had classified all presumed trees in terms of the tree's developmental stage, based on the size of their entrance holes. We tested their classification using the trees at our five study sites (see above). When we compared our field data with their data, we found that many of the trees they had classified as being in the earliest hollow stage (entrance hole < $10 \mathrm{~cm}$ ) actually did not have any cavities, just shallow injuries. Furthermore, SverdrupThygeson et al. (2010) found that the number of oak species was lower in trees in the earliest hollow stage, using the same classification as the County Administration Board. When we removed the trees in this class ( $42 \%$ of all hollow oaks), remaining trees in the County 
Administration Board data set was reasonably similar to the set of trees that we had estimated to have enough wood mould to constitute habitat for the study species; the difference was less than $35 \%$ for each of the five areas. Thus, when we used tree data from the County Administration Board we included only trees belonging to categories with at least one entrance hole $>10 \mathrm{~cm}$. We also included only oaks (Quercus robur and Q. petraea (Matt.) Liebl.), which constituted about $30 \%$ of all trees in these categories, because the study species have rarely been observed in other tree species. Trunk circumference, habitat openness, and connectivity (see above) were used in the statistical models as predictors of the probability of occurrence for each study species in each of the 9,835 trees. Since the height of the entrance hole was not estimated for these trees, we could not use that variable as a predictor. This means that we assumed that the probability of occurrence was the same in trees with hollows up to $5 \mathrm{~m}$ from the ground as in trees with hollows higher up. We have found that height has an effect on several of our study species (positive effect on the occupancy of four species, negative on one, in hollows 0-5 $\mathrm{m}$ from the ground; Ranius et al. 2010), and consequently this may result in some underestimation (or for one species overestimation) of the probability of occurrence. We overlaid a grid with a mesh size of $2 \mathrm{~km} \times 2 \mathrm{~km}$ over the county of Östergötland, and summed the probabilities of occurrence for all the trees in each cell using GIS, to get the predicted number of occupied trees in each cell. We used $2 \mathrm{~km} \times 2 \mathrm{~km}$ squares because this is the approach used in the red-listing process in Sweden (Gärdenfors 2009). The predictions were validated by comparison with known occurrences of the species. We assumed that when the predicted number was lower than a certain cut-off, the species was absent from the square, but when higher than this cut-off, the species was present. We compared the fit when using 1, 2, and 4 occupied trees as cut-off values, and used 1 as the cutoff in subsequent analyses, because it generated the best fit with field data for most of the species (see Results). Using this cut-off we predicted area of occupancy, recognizing that occupancy does not necessarily imply that the species is occurring in viable populations.

For each species, we calculated the factors of underestimation for 1993 and 2009 as the quotient between the predicted number of occupied squares and the number of squares with records known in 1993 and 2009. Old oaks constitute a long-lived and stable habitat, and therefore the change in habitat availability has been relatively small from 1993 to now. The species records come from a database managed by the Swedish Species Information Centre, 
and are the same data as used in the Swedish red-listing process. We excluded species data originating from the present study, to avoid dependence of data sets. The data base contains records from surveys, museums, and private collections. Up to 1993 there were no records made by any professional nature conservationists, and consequently almost all data were collected in a non-systematic way. However, even this dataset is quite extensive (Table 2) because entomologists have been interested for a long time in the beetle fauna in ancient trees (e.g. Jansson 1930); less attention has been paid to pseudoscorpions (see however Lohmander 1944). After 1993, systematic surveys of hollow oaks have been conducted using traps at about 100 sites, mainly in areas of conservation interest (Jansson 2006). In addition, at least ten amateurs have made significant records (Jansson 2006). One of the study species, Osmoderma eremita, has been surveyed with traps at about 150 sites (Antonsson et al. 2003). This makes Östergötland one of the most well-investigated counties in Sweden (Jansson 2006).

For body size of the species we used the mean values for adults given by Henriksen (1913), Hansen (1925; 1945), and Gärdenfors and Wilander (1992). Generalized linear modelling was conducted using R 2.9.0 (R Development Core Team 2009) and other analyses were conducted in SPSS 16.0.

\section{Results}

For six of nine species, there was a statistically significant positive relationship with trunk circumference, and for two species there was a positive relationship with habitat openness (Table 3; Fig. 2). For eight of nine species, there was a statistically significant positive relationship with connectivity. The radius of the connectivity measure that generated the best fit with the data varied between $135 \mathrm{~m}$ and 2,857 $\mathrm{m}$ among species (Table 3). The more endangered a species is according to the red list, the better its occurrence pattern was explained by its statistical model, i.e., the bigger proportion of the deviance was explained by the model ( $p=0.005$, ordinal regression). Furthermore, more endangered species tended to have a larger radius of the connectivity measure that generated the best fit to the field data ( $p$ $=0.026$, ordinal regression, Table 3).

More endangered species had smaller predicted areas of occupancy ( $p=0.017$, ordinal regression, Table 2). For all species, there was a strong positive relationship between 
predicted occurrence for each square and whether the species had been recorded there or not (Table 4; Fig. 3). For most species, the relationship between prediction and field data was stronger when one occupied tree was used as a cut-off, rather than when a higher cut-off level was used (Table 4). Therefore we used one occupied tree as a cut-off in all further analyses. A comparison between calculations based on our predictive models and species records up to the present suggested that the factors of underestimation were between 1.3 and 25. In 1993, before any systematic inventories had been conducted, the calculated factors of underestimation were between 3 and 83 . When only considering beetles, smaller species generally had larger occupancy underestimates than larger species $(p=0.011$, mixed-effect model, with year as random effect), but this relationship was not significant when the two pseudoscorpion species were also included ( $p=0.13$; Fig. 4$)$.

\section{Discussion}

Occurrence of invertebrates in hollow oaks is affected both by tree characteristics and connectivity (Fig. 2). Similar results have been obtained for tree-living bryophytes and lichens (e.g. Snäll et al. 2003; Löbel et al. 2006). The spatial scale of effect of habitat varied widely among species, but was of the same magnitude in this study in comparison to previous studies of saproxylic beetles (Holland et al. 2005, Schroeder et al. 2006, Franc et al. 2007).

The spatial scale of effect of connectivity on occupancy is thought to be positively related to the movement range of species (e.g. Schmidt et al. 2008). While this may seem inconsistent with the fact that the species with the largest spatial scale of effect was the pseudoscorpion Larca lata, which lacks the ability to fly, it is likely that this species travels long distances by phoresy (= hitch-hiking with flying animals; Poinar et al. 1998). This is consistent with the observed low genetic differentiation among local populations of this species, indicating that migration between them is frequent (Ranius and Douwes 2003). It has been argued that threatened invertebrates in hollow trees require conservation efforts very near or within occupied sites, because the dispersal range is low (Hedin et al. 2008). For one of the study beetles, Osmoderma eremita, a limited dispersal range has indeed been demonstrated by capture-recapture and telemetric studies (Hedin et al. 2008). However, we found other beetles associated with hollow trees, that are rarer and more threatened than $O$. eremita (Elater ferrugineus, Tenebrio opacus; Table 2), whose occupancies were related to 
connectivity at much larger spatial scales (Table 3). This indicates that, among our study species, the most threatened species actually disperse farther than less threatened species such as $O$. eremita. This is consistent with Thomas (2000), who found that the distributions of butterfly species with an intermediate mobility had decreased more than the distributions of both more mobile and more sedentary species. The reason why E. ferrugineus and T. opacus are more threatened than O. eremita may be that dispersal from oak woods and pastures is a poor strategy in today's fragmented landscapes, as it increases the risk for emigrants to die in the matrix, thus placing species with larger dispersal ranges at greater risk. However, the rarity of E. ferrugineus and T. opacus may also be due to other factors than migration mortality. For instance, it may be that these species tend to occur in smaller and more fluctuating populations (E. ferrugineus: Larsson and Svensson, in press), and for that reason need a larger network of hollow trees to get enough colonisations to compensate local extinctions (cf. Drechsler and Wissel 1998). We also note that since Elater ferrugineus is a predator, and larvae of Osmoderma eremita are one of its prey (Schaffrath 2003), our result is consistent with the idea that the experienced spatial scale is larger for organisms at higher trophic levels (Holt 1996).

To illustrate the differences among species in terms of the density of hollow oaks needed for a certain occupancy, we estimated for three species the density of hollow oaks required to obtain a probability of presence of at least $50 \%$ in a suitable tree (here defined as a hollow oak with a diameter of $1.2 \mathrm{~m}$, and the highest degree of habitat openness). For O. eremita, 69 hollow oaks per $\mathrm{km}^{2}$ are required within a radius of $192 \mathrm{~m}$, for E. ferrugineus, 38 hollow oaks per $\mathrm{km}^{2}$ are required within a radius of $1,104 \mathrm{~m}$, and for $T$. opacus, 10 hollow oaks per $\mathrm{km}^{2}$ are required within a radius of $2,760 \mathrm{~m}$. To obtain a continuous supply of hollow trees, younger trees are also required. A previous estimation has suggested that in an oak population with a stable age structure and only natural tree mortality (i.e. the highest density of hollow oaks possible to maintain in the long run, which we call "optimal oak pasture"), $7 \%$ of the trees have hollows with wood mould (Jonsson and Ranius 2009), and the area needed for each oak is about 0.02 ha (cf. Ranius et al. 2009b). Consequently, for O. eremita, optimal oak pasture has to cover $20 \%$ of the area within 192 m, which means an area with optimal oak pasture of 2.3 ha. For E. ferrugineus and T. opacus, the corresponding values are $11 \%$ (42 ha within $1,104 \mathrm{~m}$ ) and $3 \%$ (69 ha within 2,760 m), respectively. In Europe, regions with such high densities of hollow trees are rare today, but such densities were probably rather common in 
the old-growth broadleaved forests that originally covered wide regions in Europe. Thus, these hollow oak-dwelling species, which today are regarded as rarities, may have been common in virgin forests of Europe.

For all species, there was a strongly significant relationship between predicted and observed occurrences (Table 4). The explained deviance was relatively low mainly because the observed occupancy was much lower than predicted (i.e. the underestimation was high). For all species except L. lata, at least $63 \%$ of the occurrences were observed in squares for which occupancy was predicted, while in squares with no observed occurrences, absence was predicted in at least $81 \%$ of the sites (Table 4). Thus, the recorded observations (all observations known except those used to fit our prediction model) validated the prediction model for all species, except Larca lata. The poor fit for $L$. lata may be because the predictive model underestimates its occupancy due to false absences in our data.

When knowledge about area of occupancy was based mainly on incidental records (up to 1993), the underestimation (total area of occupancy / known area of occupancy) was between 3 and 83. For our study species, extensive and systematic surveys have decreased the underestimations to levels between 1.3 and 25. However, the lowest underestimation factor was for Larca lata, whose occurrence was predicted for only a minority of all squares where it actually occurred (Larca lata, Table 4). With Larca lata excluded, the lowest factor of underestimation was 2.4. All our underestimation factors represent minimum values, as the underlying assumptions that these estimates rely on $-i$ ) the species never use any other habitat than hollow oaks with entrances $>10 \mathrm{~cm}, \mathrm{ii}$ ) there are no false absences in our invertebrate sampling, iii) the probability of occurrence is equal in trees with hollows up to $5 \mathrm{~m}$ from the ground as in trees with hollows higher up, and $i v$ ) all hollow oaks were found in the tree survey - are unlikely to be met in all cases. Among beetles, the underestimation was larger for the smaller species (Fig. 4). An explanation for this is that among these species, mean body size is probably positively correlated both with the probability of finding specimens in the field and their identifiability (T Ranius, pers obs). Similar relationships were suggested in an analysis of polypore fungi data, which found that identifiability and longevity of fruit-bodies were the major factors affecting the number of records of different species (Lõhmus 2009). 


\section{Implications}

In the Swedish redlist the assumed factors of underestimation vary from 1 to 100, which are consistent with the magnitude of underestimation obtained in the present study. However, the Swedish redlist does not publish the factors of underestimation used for individual species (Gärdenfors 2010). In other cases, for instance IUCN's European redlist of saproxylic beetles, the potential underestimation of area of occupancy is not even considered (Nieto and Alexander 2010). The present study shows that calculations solely based on species records severely underestimate the area of occupancy. We suggest this should be taken into account to a greater extent and in a clearer way than today when constructing redlists. The generally high levels of underestimation imply that it is difficult to solve the problem of poor knowledge about threatened species simply by collecting more data on species records. Instead, a more fruitful approach is to model the habitat requirements of species based on intensive sampling in a restricted area, collect data on habitat availability, and use the obtained data to predict the current area of occupancy.

Osmoderma eremita has frequently been used as an indicator and model species representing a whole community of invertebrates associated with hollow trees (Ranius 2002b). This study shows that some species that are more threatened respond to habitat connectivity at a larger spatial scale than $O$. eremita. This suggests that to preserve all threatened species, conservation efforts will have to be conducted at larger spatial scales than the scale required to preserve O. eremita.

\section{Acknowledgements}

Rickard Andersson (previously Baranowski), Per Wilander and Stanislav Snäll helped us with identification of beetle and pseudoscorpion species. The Swedish Species Information Centre provided data on species observations and The County Administration Board of Östergötland inventory data on hollow trees. The work was funded by Formas grant 2006-232 to TR.

\section{References}

Antonsson K, Hedin J, Jansson N, Nilsson SG, Ranius T (2003) Läderbaggens (Osmoderma eremita) förekomst i Sverige. Entomol Tidskr 124: 225-240 [Occurrence of the hermit beetle (Osmoderma eremita) in Sweden. In Swedish, English abstract] 
Claesson K, Ek T (2009) Skyddsvärda träd i Östergötland - 1997-2008. Rapport 2008: 13. Länsstyrelsen Östergötland, Linköping [In Swedish]

Drechsler M, Wissel C (1998) Trade-offs between local and regional scale management of metapopulations. Biol Conserv 83: 31-41

Eigenbrod F, Hecnar SJ, Fahrig L (2011) Sub-optimal study design has major impacts on landscape-scale inference. Biol Conserv 144: 298-305

Fahrig L (2007) Non-optimal animal movement in human-altered landscapes. Funct Ecol 21: $1003-1015$

Franc N, Götmark F, Økland B, Nordén B, Paltto H (2007) Factors and scales potentially important for saproxylic beetles in temperate mixed oak forest. Biol Conserv 135: 86-98

Gärdenfors U (ed) (2010) The 2010 red list of Swedish species. Swedish Species Information Centre, Uppsala

Gärdenfors U (2009) Manual och riktlinjer för rödlistning i Sverige 2010. Version 2009-0611. Swedish Species Information Centre, Uppsala [In Swedish]

Gärdenfors U, Wilander P (1992) Sveriges klokrypare med nyckel till arterna. Entomol Tidskr 113: 20-35 [Swedish pseudoscorpions with a key to the species. In Swedish]

Hallingbäck T, Hodgetts N, Raeymaekers G, Schumacker R, Sérgio C, Söderström L, Stewart N, Váňa J (1998) Guidelines for application of the revised IUCN threat categories to bryophytes. Lindbergia 23: 6-12

Hansen V (1925) Danmarks fauna 29. Biller VI. Torbister. GEC Gads forlag, Copenhagen [In Danish]

Hansen V (1945) Danmarks fauna 50. Biller XII. Heteromerer. GEC Gads forlag, Copenhagen [In Danish]

Hedin J, Ranius T, Nilsson SG, Smith HG (2008) Restricted dispersal in a flying beetle assessed by telemetry. Biodiv Conserv 17: 675-684

Henriksen K (1913) Danmarks fauna 14. Biller II. Pragtbiller og smeldere. GEC Gads forlag, Copenhagen [In Danish]

Holland JD, Fahrig L, Cappuccino N (2005) Body size affects the spatial of habitat-beetles interactions. Oikos 110: 101-108 
Holt RD (1996) Food webs in space: an island biogeographic perspective. In: Food webs integration of patterns and dynamics (eds: Polis GA, Winemiller KO). Chapman \& Hall, London. pp 313-323

Jansson A (1930) De gamla träden och deras inbyggare. Örebro läns naturskyddsförenings årsskrift, pp 61-68 [In Swedish]

Jansson N (2006) Vedlevande skalbaggar, myror och klokrypare på gamla ädellövträd i Östergötland. Länsstyrelsen Östergötland, Linköping [In Swedish]

Johst K, Brandl R, Eber S (2002) Metapopulation persistence in dynamic landscapes: the role of dispersal distance. Oikos 98: 263-270

Jonsson BG, Ranius T (2009) The temporal and spatial challanges of target setting for dynamic habitats: the case of dead wood and saproxylic species in boreal forests. In: Setting conservation targets for managed forest landscapes (eds: Villard M-A, Jonsson BG). Cambridge University Press, Cambridge. pp 207-226

Komonen A, Jonsell M, Ranius T (2008) Red-listing saproxylic beetles in Fennoscandia: current status and future perspectives. Endangered Species Research 6: 149-154

Kotiaho JS, Kaitala V, Komonen A, Päivinen J (2005) Predicting the risk of extinction from shared ecological characteristics. P Natl Acad Sci USA 102: 1963-1967

Larsson, MC, Svensson GP (2011) Monitoring spatiotemporal variation in abundance and dispersal by a pheromone-kairomone system in the threatened saproxylic beetles Osmoderma eremita and Elater ferrugineus. J Insect Conservation, in press. DOI 10.1007/s10841-011-9388-5

Löbel S, Snäll T, Rydin H (2006) Species richness patterns and metapopulation processes evidence from epiphyte communities in boreo-nemoral forests. Ecography 29: 169-182

Lohmander H (1944) Om klokrypare och gamla träd. Sveriges Natur p 95 [In Swedish]

Lõhmus A (2009) Factors of species-specific detectability in conservation assessments of poorly studied taxa: The case of polypore fungi. Biol Conserv 142: 2792-2796

Maes D, van Dyck H (2001) Butterfly diversity loss in Flanders (north Belgium): Europe's worst case scenario? Biol Conserv 99: 262-276

Martin O (1993) Fredede insekter i Danmark. Del 2: Biller knyttet til skov. Entomologiske Meddelelser 57: 63-76 [In Danish, English summary] 
Newton AC, Oldfield S (2008) Red Listing the world's tree species: a review of recent progress. Endangered Species Research 6: 137-147

Nieto A, Alexander KNA (2010) European Red List of Saproxylic Beetles. Publications Office of the European Union, Luxembourg

Poinar GO Jr, Ćurčić BPM, Cokendolpher JC (1998) Arthropod phoresy involving pseudoscorpions in the past and present. Acta Arachnol 47: 79-96

Quinn GP, Keough MJ (2002) Experimental design and data analysis for biologists. Cambridge University Press, Cambridge

R Development Core Team (2009) R: a language and environment for statistical computing. $R$ Foundation for Statistical Computing, Vienna

Ranius T (2002a) Influence of stand size and quality of tree hollows on saproxylic beetles in Sweden. Biol Conserv 103: 95-91

Ranius T (2002b) Osmoderma eremita as an indicator of species richness of beetles in tree hollows. Biodiv Conserv 11: 931-941

Ranius T, Douwes P (2003) Genetic structure of two pseudoscorpion species living in tree hollows in Sweden. Anim Biodiv Conserv 25.2: 67-74

Ranius T, Jansson N (2002) A comparison of three methods to survey saproxylic beetles in hollow oaks. Biodiv Conserv 11: 1759-1771

Ranius T, Nilsson SG (1997) Habitat of Osmoderma eremita Scop., Coleoptera: Scarabaeidae), a beetle living in hollow trees. J Insect Conserv 1: 193-204

Ranius T, Wilander P (2000) Occurrence of Larca lata H.J. Hansen (Pseudoscorpionida: Garypidae) and Allochernes wideri C.L. Koch (Pseudoscorpionida: Chernetidae) in tree hollow in relation to habitat quality and density. J Insect Conserv 4: 23-31

Ranius T, Svensson GP, Berg N, Niklasson M, Larsson MC (2009a) The successional change of hollow oaks affects their suitability for an inhabiting beetle, Osmoderma eremita. Ann Zool Fenn 46: 205-216

Ranius T, Niklasson M, Berg N (2009b) Development of tree hollows in pedunculate oak (Quercus robur). For Ecol Manage 257: 303-310

Ranius T, Johansson V, Fahrig L (2010) A comparison of patch connectivity measures using data on invertebrates in hollow oaks. Ecography 33: 971-978 
Schaffrath U (2003) Zu Lebensweise, Verbreitung und Gefährdung von Osmoderma eremita, (Scopoli, 1763) (Coleoptera; Scarabaeoidea, Cetoniidae, Trichiinae), Teil 2. Phillipia 249: $249-336$

Schmidt MH, Thies C, Nentwig W, Tscharntke T (2008) Contrasting responses of arable spiders to the landscape matrix at different spatial scales. J Biogeography 35: 157-166

Schroeder LM, Ranius T, Ekbom B, Larsson S (2006) Recruitment of saproxylic beetles in high stumps created for maintaining biodiversity in a boreal forest landscape. Can J For Res 36: 2168-2178

Snäll T, Ribeiro Jr PJ, Rydin H (2003) Spatial occurrence and colonisations in patch-tracking metapopulations: local conditions versus dispersal. Oikos 103: 566-578

Sverdrup-Thygeson A, Skarpaas O, Ødegaard F (2010) Hollow oaks and beetle conservation: the significance of the surroundings. Biodiv Conserv 19: 837-852

Thomas CD (2000) Dispersal and extinction in fragmented landscapes. P Roy Soc B - Biol Sci 267: $139-145$ 
Table 1. Characteristics of the five study areas in the county of Östergötland, southeast

Sweden (Fig. 1), in which beetles and pseudoscorpions in hollow oaks were sampled.

\begin{tabular}{|c|c|c|c|c|c|}
\hline Name & $\begin{array}{l}\text { Coordinates } \\
\text { (midpoints) }\end{array}$ & $\begin{array}{l}\text { Size } \\
\left(\mathrm{km}^{2}\right)\end{array}$ & $\begin{array}{l}\text { Hollow } \\
\text { oaks } / k^{2}{ }^{2}\end{array}$ & $\begin{array}{l}\text { No. sampled } \\
\text { trees }\end{array}$ & $\begin{array}{l}\text { Sample } \\
\text { year }\end{array}$ \\
\hline Bjärka Säby & $58^{\circ} 16^{\prime} \mathrm{N}, 14^{\circ} 45^{\prime} \mathrm{E}$ & 1.3 & 79.2 & 46 & 2000 \\
\hline Kättilstad & $58^{\circ} 04^{\prime} \mathrm{N}, 15^{\circ} 50^{\prime} \mathrm{E}$ & 201.0 & 1.0 & 127 & 1996 \\
\hline Omberg & $58^{\circ} 21^{\prime} \mathrm{N}, 14^{\circ} 39^{\prime} \mathrm{E}$ & 22.5 & 11.7 & 41 & 2007 \\
\hline Sankt Anna & $58^{\circ} 24^{\prime} \mathrm{N}, 16^{\circ} 52^{\prime} \mathrm{E}$ & 32.7 & 6.3 & 26 & 1997-98 \\
\hline Skärkind & $58^{\circ} 28^{\prime} \mathrm{N}, 16^{\circ} 01^{\prime} \mathrm{E}$ & 94.7 & 1.5 & 41 & 2007 \\
\hline
\end{tabular}


Table 2. Observed and predicted occupancy per $2 \mathrm{~km} \times 2 \mathrm{~km}$ squares in the county of Östergötland, Sweden.

$\begin{array}{lrrrrrrrr}\text { Species } & \text { Red } & \text { Records } & \text { Records } & \text { Occ. } & \text { Occ. } & \text { Occ. } & \text { U-est. } & \text { U-est. } \\ & \text { list } & \mathbf{1 9 9 3} & \mathbf{2 0 0 9} & \mathbf{1 9 9 3} & \mathbf{2 0 0 9} & \text { pred. } & \mathbf{1 9 9 3} & \mathbf{2 0 0 9} \\ \text { Allochernes wideri (P) } & \text { LC } & 10 & 47 & 0.2 \% & 0.8 \% & 19.6 \% & 82.6 & 24.5 \\ \text { Ampedus hjorti (B) } & \text { LC } & 54 & 192 & 0.5 \% & 2.0 \% & 13.7 \% & 28.9 & 7.0 \\ \text { Allecula morio (B) } & \text { NT } & 42 & 261 & 0.7 \% & 2.4 \% & 17.3 \% & 24.3 & 7.1 \\ \text { Ampedus cardinalis (B) } & \text { NT } & 49 & 203 & 0.7 \% & 1.8 \% & 11.4 \% & 17.5 & 6.2 \\ \text { Larca lata (P) } & \text { NT } & 4 & 93 & 0.1 \% & 1.5 \% & 2.0 \% & 16.8 & 1.3 \\ \text { Osmoderma eremita (B) } & \text { NT } & 158 & 828 & 1.3 \% & 4.7 \% & 15.8 \% & 12.1 & 3.4 \\ \text { Procraerus tibialis (B) } & \text { NT } & 59 & 196 & 0.4 \% & 1.9 \% & 15.9 \% & 35.8 & 8.5 \\ \text { Elater ferrugineus (B) } & \text { VU } & 44 & 132 & 0.4 \% & 0.6 \% & 1.4 \% & 3.3 & 2.4 \\ \text { Tenebrio opacus (B) } & \text { VU } & 53 & 112 & 0.3 \% & 0.7 \% & 4.3 \% & 13.2 & 6.3\end{array}$

Beetle (B) and pseudoscorpion (P) species of study; Red list = red list categories in Sweden $(\mathrm{VU}=$ vulnerable; $\mathrm{NT}=$ near threatened; $\mathrm{LC}=$ least concern; Gärdenfors 2010); Records 1993 $=$ number of records in 1993 or earlier; Records $2009=$ number of records in 2009 or earlier; Occ. $1993=$ proportion of squares with records in 1993 or earlier; Occ. $2009=$ proportion of squares with records in 2009 or earlier; Occ. pred. = proportion of occupied squares according to the predictive model; U-est. $1993=$ factor of underestimation $(=$ number of predicted occurrences / known occurrences) of the number of occupied squares, if only records in 1993 or earlier are considered; U-est. $2009=$ factor of underestimation of the number of occupied squares, if records up to 2009 are considered. Total number of squares: 3,378. 
Table 3. Study species, red list categories in Sweden, occupancy per tree (Occ.), and, for the most parsimonious (lowest AIC value) multiple logistic regression model of species' presence/absence per tree: intercept, coefficients, radius of the connectivity measure (Radius) and explained deviance (Exp. dev.). Data from 281 hollow oaks in southeastern Sweden (Fig. 1).

\begin{tabular}{lrrrlllrr} 
Species & $\begin{array}{r}\text { Red } \\
\text { list }\end{array}$ & Occ. & $\begin{array}{l}\text { Inter } \\
\text { cept }\end{array}$ & $\begin{array}{l}\text { Open } \\
\text { ness }\end{array}$ & Circum & $\begin{array}{l}\text { Connect } \\
\text { ivity }\end{array}$ & $\begin{array}{l}\text { Radi } \\
\text { us }\end{array}$ & \multicolumn{1}{l}{$\begin{array}{l}\text { Exp. } \\
\text { dev. }\end{array}$} \\
Allochernes wideri (P) & LC & $31 \%$ & -1.07 & 0.286 & & & 1351 & $1.2 \%$ \\
Ampedus hjorti (B) & LC & $31 \%$ & -2.39 & & 0.00265 & 0.0340 & 384 & $5.4 \%$ \\
Allecula morio (B) & NT & $37 \%$ & -2.72 & & 0.00503 & 0.0100 & 919 & $12.4 \%$ \\
Ampedus cardinalis (B) & NT & $25 \%$ & -3.52 & 0.793 & 0.00271 & 0.0404 & 329 & $10.3 \%$ \\
Larca lata (P) & NT & $7 \%$ & -8.13 & 0.725 & 0.00549 & 0.0211 & 2857 & $30.5 \%$ \\
Osmoderma eremita (B) & NT & $37 \%$ & -1.96 & 0.685 & & 0.0740 & 192 & $10.9 \%$ \\
Procraerus tibialis (B) & NT & $35 \%$ & -2.68 & & 0.00429 & 0.0132 & 911 & $7.6 \%$ \\
Elater ferrugineus (B) & VU & $6 \%$ & -5.23 & 0.278 & & 0.0323 & 1104 & $21.9 \%$ \\
Tenebrio opacus (B) & VU & $15 \%$ & -6.86 & & 0.00918 & 0.0141 & 2760 & $23.8 \%$
\end{tabular}

${ }^{1}$ in the most parsimonious model for $A$. wideri the connectivity variable was excluded. When included, the relationship was positive. 
Table 4. Relationships between predicted occurrence per $2 \mathrm{~km} \times 2 \mathrm{~km}$ square and occurrence records up to 2009 for each species. All relationships were positive and all were significant at $p<0.001$. "Limit $=1$ ": the species is considered "present" in a square if it is predicted to be present in at least one tree. For "Limit $=2$ " and "Limit $=4$ " the cut-off level for when a species is considered "present" in a square is two or four trees, respectively. Explained deviance from generalized linear model with binomial distribution and logit link function (dependent variable: presence/absence in records, independent variable: predicted presence/absence). For each species, the highest value of the explained deviance is in bold.

$\begin{array}{lrrrrrr}\text { Species } & \text { Red list } & \begin{array}{r}\text { Limit = 1 } \\ \text { Explained } \\ \text { Deviance }\end{array} & \begin{array}{r}\text { Prop. occupied } \\ \text { squares with } \\ \text { occurrence predicted }\end{array} & \begin{array}{r}\text { Prop. absent } \\ \text { squares with } \\ \text { absence predicted }\end{array} & \begin{array}{r}\text { Limit = 2 } \\ \text { Explained } \\ \text { Deviance }\end{array} & \begin{array}{r}\text { Limit =4 } \\ \text { Explained } \\ \text { Deviance }\end{array} \\ \text { Allochernes wideri (P) } & \text { LC } & 17.4 \% & 85.2 \% & 81.0 \% & 22.4 \% & \mathbf{2 3 . 0 \%} \\ \text { Ampedus hjorti (B) } & \text { LC } & 20.8 \% & 75.8 \% & 87.6 \% & \mathbf{2 2 . 1 \%} & 16.6 \% \\ \text { Allecula morio (B) } & \text { NT } & 21.1 \% & 80.5 \% & 84.3 \% & \mathbf{2 4 . 5 \%} & 19.6 \% \\ \text { Ampedus cardinalis (B) } & \text { NT } & \mathbf{2 0 . 2 \%} & 71.0 \% & 89.7 \% & 17.5 \% & 11.5 \% \\ \text { Larca lata (P) } & \text { NT } & \mathbf{1 1 . 8 \%} & 30.0 \% & 98.4 \% & 7.8 \% & 3.5 \% \\ \text { Osmoderma eremita (B) } & \text { NT } & \mathbf{1 8 . 8 \%} & 69.4 \% & 86.8 \% & 16.2 \% & 12.1 \% \\ \text { Procraerus tibialis (B) } & \text { NT } & 24.7 \% & 85.7 \% & 85.5 \% & 17.5 \% & \mathbf{2 5 . 5 \%} \\ \text { Elater ferrugineus (B) } & \text { VU } & \mathbf{3 4 . 8 \%} & 63.2 \% & 99.0 \% & 26.0 \% & 14.0 \% \\ \text { Tenebrio opacus (B) } & \text { VU } & \mathbf{3 3 . 4 \%} & 78.3 \% & 96.2 \% & 31.5 \% & 20.9 \%\end{array}$




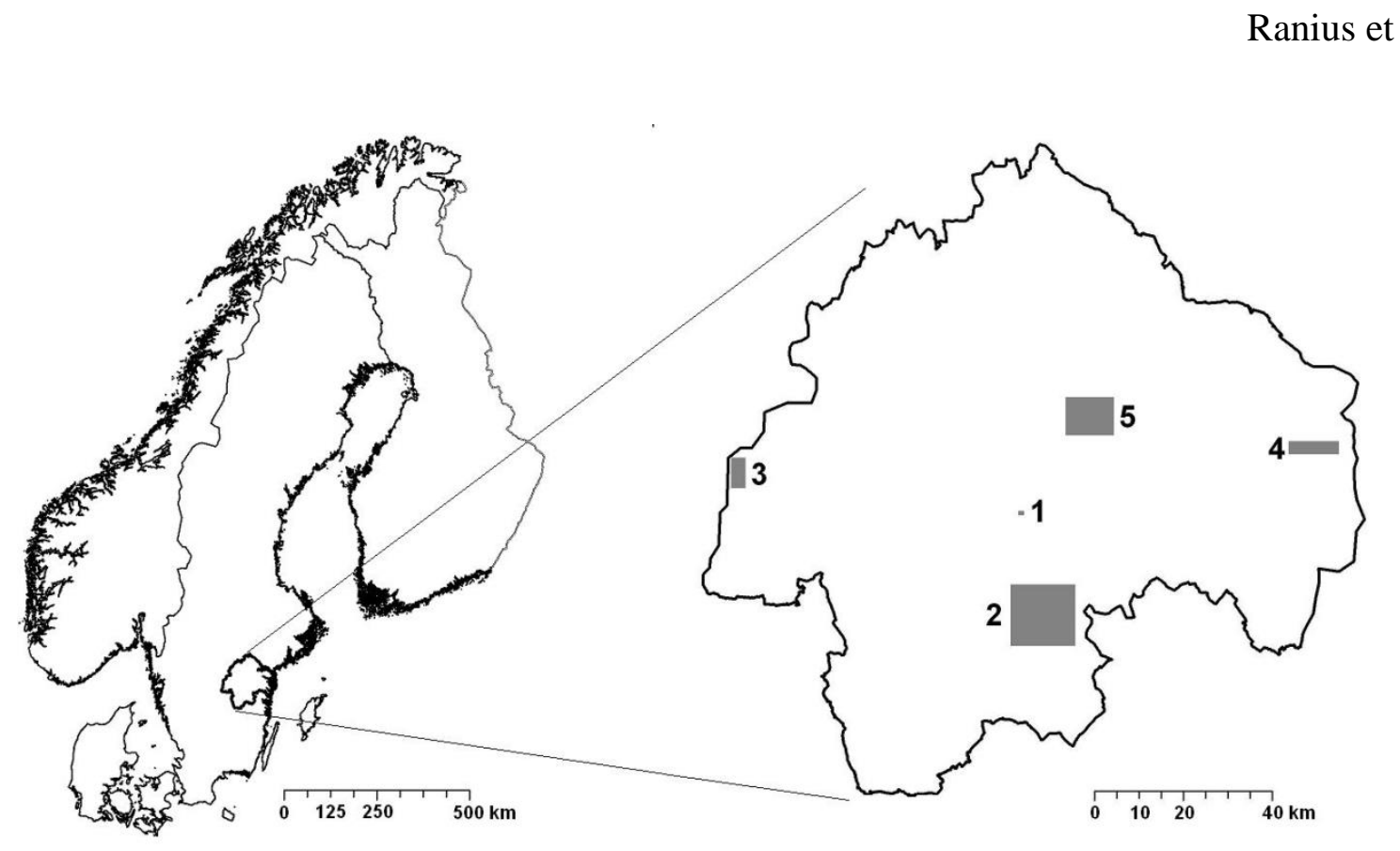

Fig. 1. Study areas in the county of Östergötland, Sweden. 1. Bjärka Säby; 2. Kättilstad; 3. Omberg; 4. Sankt Anna; 5. Skärkind. 


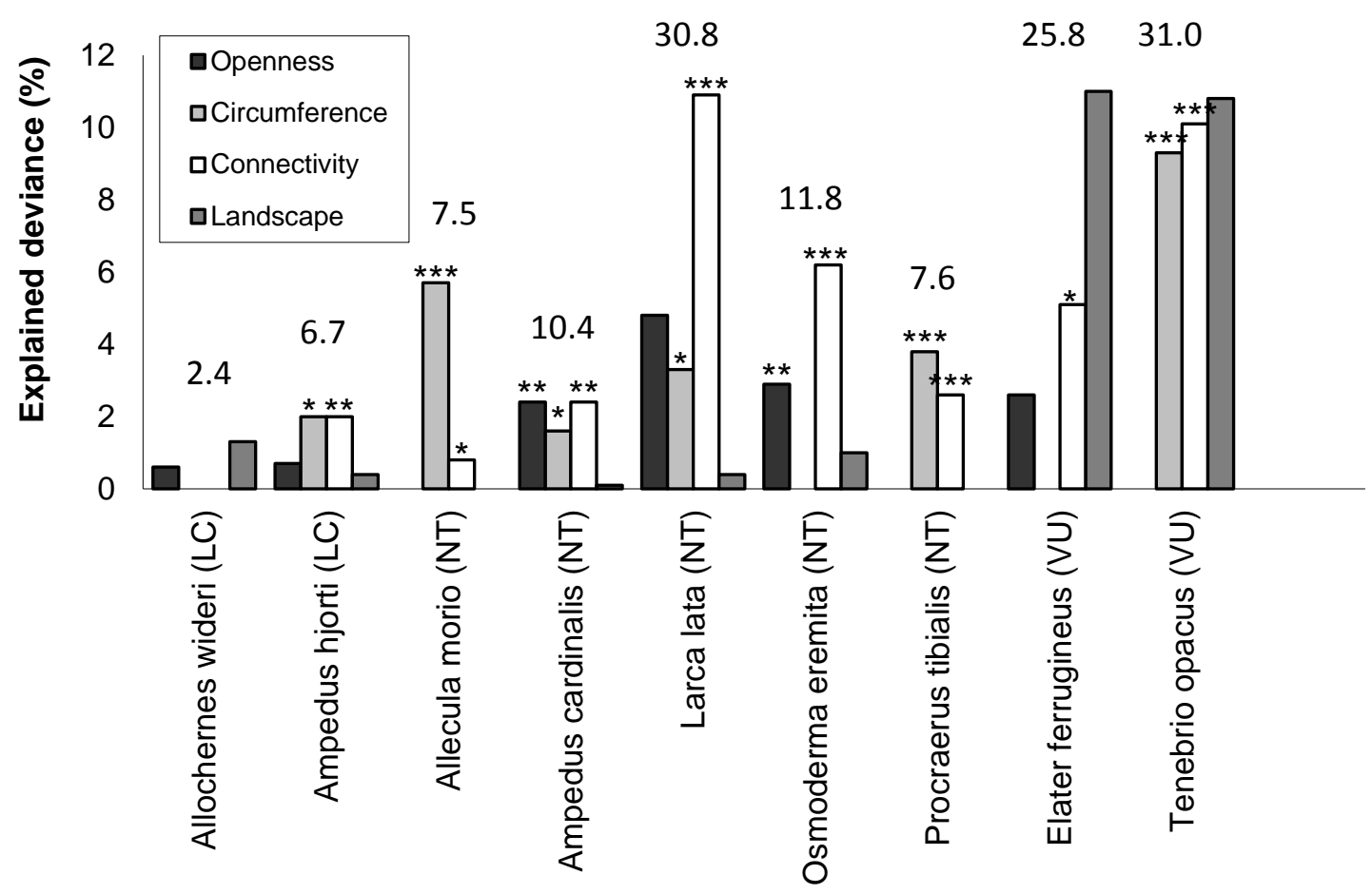

Fig. 2. The increase in explained deviance (\%) of logistic regression models when adding different independent variables to the most parsimonious model but with this variable absent. Species presence/absence per tree is the dependent variable, habitat openness, trunk circumference, and connectivity (number of surrounding trees) are the independent fixed factors, and landscape identity is a random factor. All relationships were positive. If inclusion of the variable did not lower the AIC value, the explained deviance was reported as 0 . For variables at the tree level, significance levels are given as *, $p<0.05 ; * *, p<0.01 ; * * *, p<$ 0.001. The total explained deviance for the models are given as figures above the bars. $\mathrm{VU}=$ vulnerable; $\mathrm{NT}=$ near threatened; $\mathrm{LC}=$ least concern. 

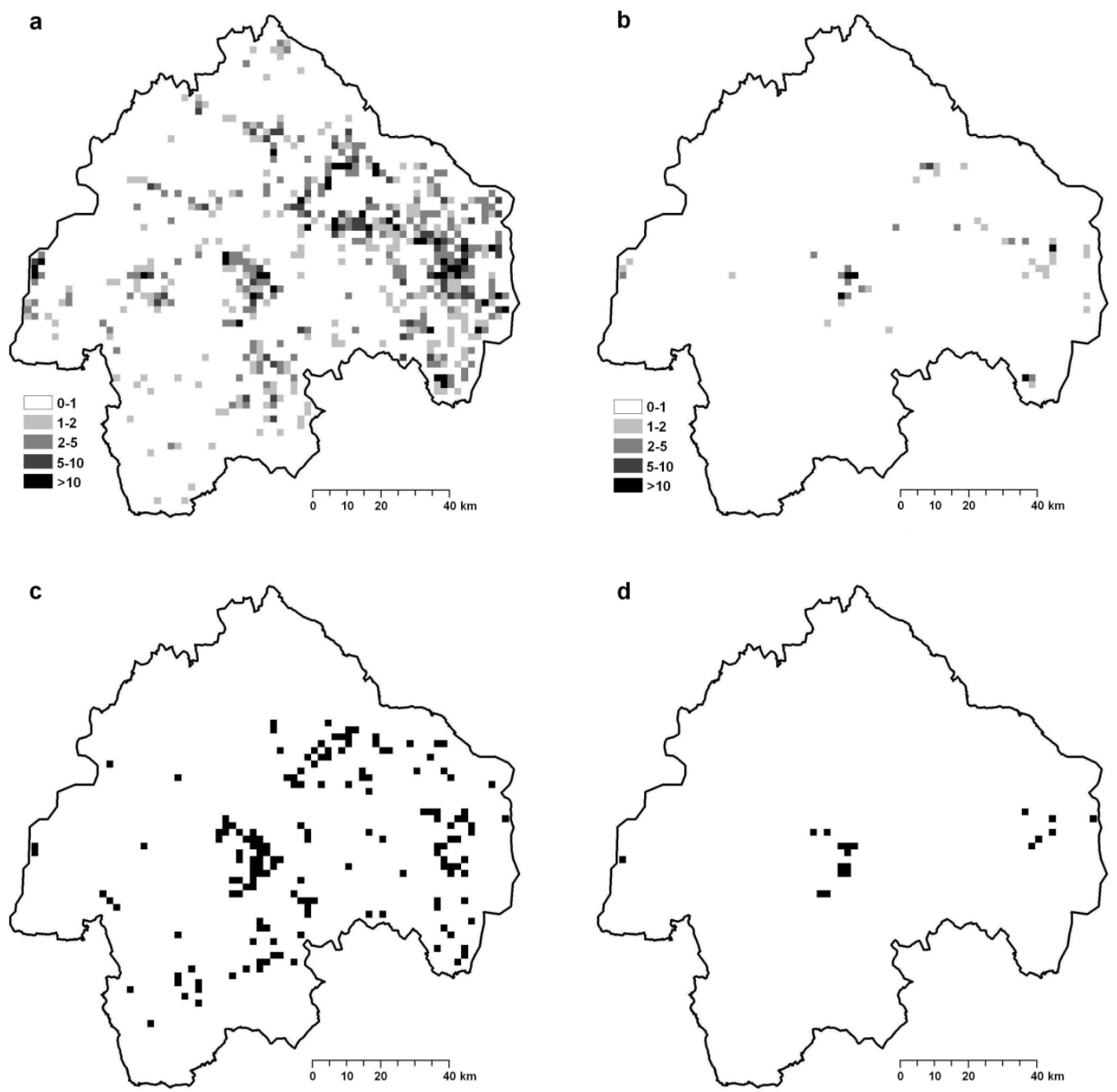

Fig. 3. Two examples of species' occurrences in the county of Östergötland, Sweden. a) predicted for Osmoderma eremita Scopoli; b) predicted for Elater ferrugineus L.; c) observed up to 2009 for O. eremita; d) observed up to 2009 for E. ferrugineus. The grey-scale represents the predicted number of occupied oaks per square. 


\section{3}

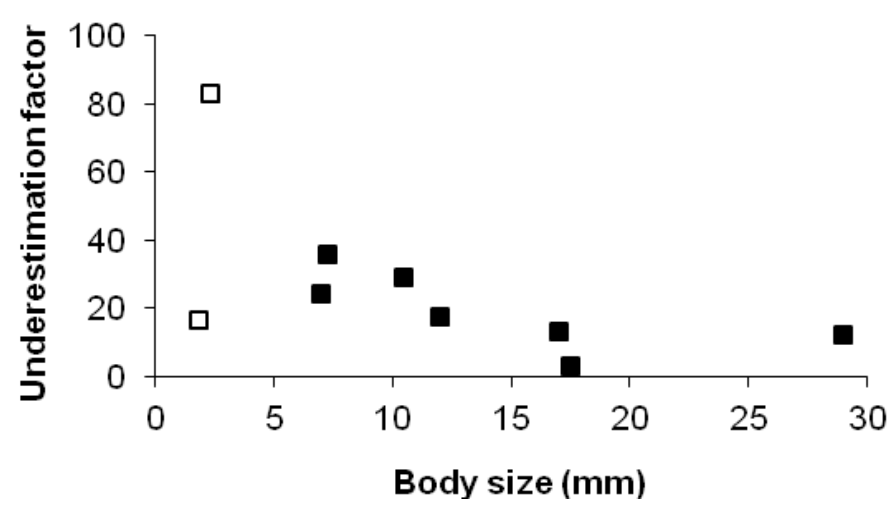

\section{9}

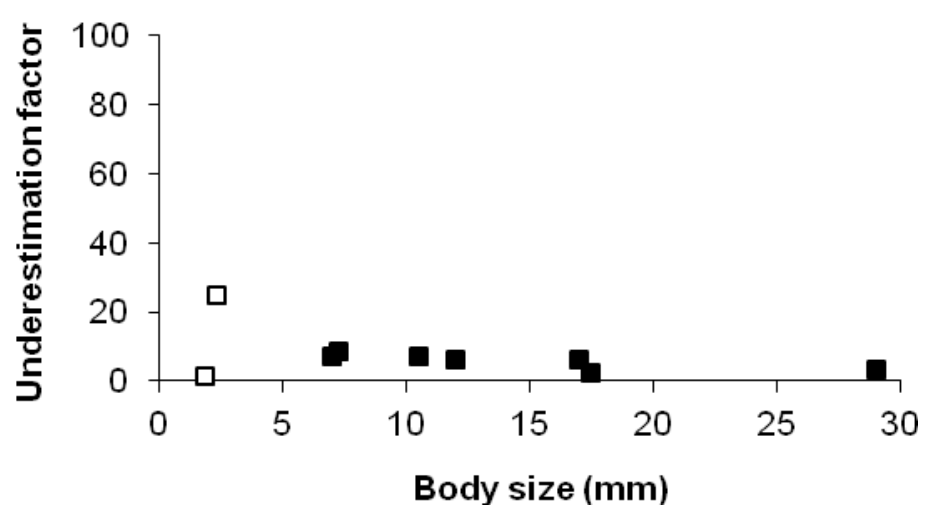

Fig. 4. Relationship between adult body size of beetles (filled) and pseudoscorpions (open squares) and the factor of underestimation (the ratio of the area of occupancy based on predictive modelling to the area of occupancy based on occurrence records) if records are included $i$ ) from 1993 and earlier, or ii) from 2009 and earlier. 